\title{
History and prospects of plant sexual reproduction congresses, the IASPRR and sexual plant reproduction
}

\author{
M. T. M. Willemse
}

Published online: 9 May 2008

(C) The Author(s) 2008

\section{History}

As we enter the 21st year of the journal Sexual Plant Reproduction, it seems both fitting and appropriate to consider the genesis both of this journal and its parent organization, the International Association for Sexual Plant Reproduction Research (IASPRR)_particularly through its much longer history of plant sexual reproduction congresses, informal interactions and this area of scientific pursuit as it is transformed in the modern era.

Interestingly, the parent organization for the journal did not formally exist until 2 years after Sexual Plant Reproduction was first published in 1988. The IASPRR was formally founded in Leningrad (now St. Petersburg) in 1990 and since that time has represented scientists working on various aspects of plant sexual reproduction ranging from molecular to structural levels. Nowadays, there are frequent congresses and workshops all over the world where scientists report their work on plant sexual reproduction, from the local level to regional, national and international meetings. The congress series under the auspices of the IASPRR, however, is the only one with a long history and an exclusive focus on all aspects of sexual plant reproduction providing researchers around the globe with a unique opportunity to discuss most recent progress and

M. T. M. Willemse

Wageningen University and Research Center, Arboretumlaan 4, 6703BD Wageningen, The Netherlands

Present Address:

M. T. M. Willemse ( $\square)$

Bennekomseweg 38a, 6717LM Ede, The Netherlands

e-mail: mtm.willemse@xs4all.nl developments in the field. Additionally, there have been periodic Eastern European Plant Embryology congresses, a symposium series on Frontiers in Sexual Plant Reproduction was initiated in 2000, as well as some other topical congresses of a more local nature. Increasingly, emerging molecular data has made sexual plant reproduction a popular topic at national and international botany and plant biology conferences.

The science of sexual plant reproduction has a long history that reaches beyond the 315 years interval since Camerarius uncovered the sexuality of plants (Žárský and Tupý 1995), passing 150 years of neglect before the discovery of gametes, and then a great period of exploration in the 1800 s concluding with the discovery of double fertilization in 1898 by Nawashin. It could be argued that our true classical era diminished with the untimely death of Prof. Panchanan Maheshwari, but he was notably present at the first congress in this series. In the same volume where van der Pluijm (1964) presented the first ultrastructural findings on degenerate synergid participation in receiving pollen tubes, Prof. Maheshwari asked astute questions on his findings (see Linskens 1964). This modern era included electron microscopic findings and witnessed the rise of molecular biology to answer questions in plant reproduction. Famous names and schools attended these conferences that preceded the founding of IASPRR and conference proceedings chronicle the collected data and ideas leading to concepts that sustain the science of today (Kapil 1967; Hesse 1987; Cresti and Linskens 1999).

Over the last 50 years, the number of congresses has increased (Mulcahy et al. 1986; Ottaviano et al. 1992; Bednara 1996; Kuta 2005), and congresses, workshops and newsletters relating to plant sexual reproduction have gradually increased to their current position. In the first half 
of the 20th century, scientists in India, France, the USA and the former Soviet Union made noted accomplishments in examining embryogenesis in most of the major plant families; there was significant progress on sexual reproduction research. A congress in New Delhi (Maheshwari 1962) was conspicuous evidence of the relatively high attention that scientists were beginning to devote to plant embryology, which was just entering a new area of ultrastructural studies and experimentation. Such activities stimulated this science and progress on plant sexual reproduction spread to laboratories around the world, including influential labs in Western Europe. It was in this context that the IASPRR Congresses originated. The initiation of significant newsletters and growing international cooperation was also a reason to start with the specialized journal Sexual Plant Reproduction.

\section{Early European congresses}

A congress in Nijmegen, the Netherlands, organized by Prof. Hans Ferdinand Linskens in 1963 can be noted as a basal influence on the coming activities in this area in Western Europe. This congress reported international participation from 15 countries, which included even some Eastern European countries (Linskens 1964). Presented were various aspects of plant reproduction such as chemotropism, embryo sac physiology and incompatibility barriers. The use of novel physiological and ultrastructural techniques was demonstrated during this congress.

In the 1960s, Western and Eastern Europe were strictly separated, but France was one of the first countries which started a cultural agreement with the former USSR. Within this context, Prof. Michel Favre-Duchartre organized a congress in Paris, France in 1969 in which about 20 Russian scientists, along with a translator who knew French, were permitted to pass across borders and participated with French, Belgian, Czech, Dutch and Indian scientists who attended this meeting. Cytology, ultrastructure and morphology were the leading disciplines, and several days of talks ensued on sexual reproduction with particular focus on fertilization and the diaspore. About 50 participants attended this East-West meeting, and the organizer was able to make this a pleasant gathering, in spite of no congress dinner, no photograph, no site seeing excursion and no English spoken.

The Paris congress encouraged Prof. Favre-Duchartre to hold further such scientific meetings, and in 1970, he organized a congress in Reims, France. Consistent with research interests at University of Reims, reproduction of gymnosperms using mainly cytological techniques had special attention. French scientists were in majority, but participants also included scientists from Russia, Poland,
Romania, India, Germany, United Kingdom, Sweden and The Netherlands. A social event was held in the home of Favre-Duchartre and all had a very good evening, made even more memorably with French folk songs sung by the professor, accompanied by his wife on the grand piano. It was at this meeting that Prof. Michel Favre-Duchartre proposed to continue to hold plant sexual reproduction congresses in Europe every 2 years, with a distinct preference for France serving as host, but also asking that colleagues organize congresses from time to time. This tradition gave the organizer full responsibility to select topics, place and time, but also to organize finances, as well, and this tradition persists today.

The next congress was in 1972 in Siena, Italy, by Prof. Giacomino Sarfatti. At this meeting, 68 scientists from 12 different countries participated. Although the official title of the congress was "From Ovule to Seed" broader topics were presented, including stamen and pollen. The study of plant reproduction was developing, as the use of in vitro techniques allowed questions such as the function of the endosperm in vivo to be address experimentally. There was also discussion on how to delimit the new term "progamic phase" between pollination and fertilization.

In 1974, Prof. Linskens organized the next congress, "Fertilization in Higher Plants", in Nijmegen, The Netherlands. The proceedings recorded a number of papers on the progamic phase and incompatibility, but nearly any on the diaspore. There was a call to a more experimental and biochemical approach, and sexual reproduction research was called to a higher goal of "Food for Peace".

The Congress returned to Reims, France in 1976 and Prof. Michel Favre-Duchartre first numbered it as the V International Congress. It was attended by scientists of even more nationalities. Attending meetings in the West was extremely expensive for Russian participants, given currency exchange restrictions and rates of exchange. Those from Eastern Europe found that dinner was restricted to an apple because of limitations in obtaining Western money.

In 1978, the congress moved behind the "Iron Curtain" and was held in Lublin, Poland, organized by Prof. Bohdan Rodkiewicz. At that time, the Soviet regime dominated Eastern Europe and for most Western European scientists, it was their first visit to the communist East. About 80 participants of 15 countries became acquainted with diverse research topics, mostly with a cytological approach. There was English spoken, a group photograph and social events were organized. The congress dinner was a testament to the dedication of scientists to flourish under bleak conditions. As participants learned that the organizers had forgone meat for three months to collect enough ration tickets to serve meat at the banquet, it became apparent how special a place the meeting had. 
Prof. Favre-Duchartre invited the University of Bordeaux to organize the congress in 1980. Unfortunately, the organizer had to cancel this event as the arrangements never proceeded.

In 1982 Prof. Olga Erdelska organized the congress in the High Tatra, Czechoslovakia. More than 120 scientists from about 15 countries participated in a program, with an emphasis on fertilization, apomixis and seed production. The venue was unique and the scientists enjoyed the environment by taking personal short trips and an organized long walk through the mountains. The congress concluded with a mass barbeque in all cheerfulness.

In 1984, Prof. Michiel Willemse organized the congress in Wageningen, the Netherlands. The congress was the first at which a number of posters were presented. An attempt was made to introduce sexual reproduction in ferns and mosses into the congress and some lectures were given on these plants. In general, these groups of plants were seldom presented and the following congresses have devoted their attention to the angiosperms and some gymnosperms.

Some congress programs or books have been ornamented with a logo. Although today a logo is quite common, the logos presented during the past congresses was a novelty that often reflected the selection of topic in its final model. Some early logos illustrate artistic attempts to capture the essence of the congress, as shown in Fig. 1, which displays logos for Nijmegen 1963, Nijmegen 1974, High Tatra 1982, and Wageningen 1984 on the top. The interlocked anther and ovule symbol represents a common symbol that well reflects the later organization.

In 1986, the congress was held in Reims, France. The organizer, Prof. Favre-Duchartre, retired that year from the University. He restricted the congress to higher plants and 70 participants enjoyed a typical Reims Congress. During this congress, he handed over the responsibility for the congress series to Prof. Michiel Willemse, who had already been involved in organizing congresses with Prof. FavreDuchartre. Prof. Favre-Duchartre asked the new convener not to go outside Europe with the congress series. The organization of the next congress was already known. However, to assure a better progress of the series, the convener asked some colleagues in advance to host the meeting, since in some cases it was necessary to make contracts 3 or even 4 years in advance to organize the meeting. The criteria to appoint an organizer included the presence of a productive scientific group as organizing center and an attractive place, easy to reach for international scientists. The convener points also to the publication of a presentation, in a book or special volume, of results from the conference to increase the impact of the science.

In 1988, Prof. Mauro Cresti organized the congress again in Siena, Italy, which was the X Congress. There were nine sessions of lectures and three poster sessions, and the congress book collected 72 contributions including also aspects of plant breeding. Remarkable was the presence of some Chinese scientists. During this congress, plans coalesced to found an international association, and it became gradually clear that the congress series had earned an international name, covering many aspects of sexual plant reproduction, and the number of participants and nationalities were still increasing. Before 1980, the number of participants was around 50-80, and this increased to more than 120 in the following congresses with some exceptions of more than 300 participants.

In 1990, the congress was held in Leningrad, Russia and was organized by Prof. Tatyana Batygina. There were about 500 participants, most from Russia and a lot of papers in double sessions and posters. The congress offered mostly morphological contributions, and provided a showcase for work done on plant sexual reproduction in Russia.

During this congress, the IASPRR was formally founded, and the participants agreed on the constitution and bylaws. The first board was elected, with Prof. R. Bruce Knox as President. To continue the former model, there was an intention made to switch off the congress series from Europe to abroad.

Congress logos developed during this period gave still a more or less specialized image, or focused on reproduction with text date or number. The logo of 1990 already displayed characteristics that would appear again in future themes of the next period.

\section{The IASPRR congresses}

In Ohio, USA, 1992, Prof. William Jensen organized the XII International Congress on Sexual Reproduction, which was the first congress under the auspices of the IASPRR. With a high number of participants and a balanced program, this congress was marked by the introduction of the first steps of the plant genomics applied to sexual reproduction and from that moment the more morphological approaches started to diminish. This signal for the future became also visible during the congress dinner where an extra-terrestial occupied the dinner room. Unfortunately, a congress publication of the lectures could not be realized.

The XIII International Congress was held in Vienna, Austria, in 1994. Prof. Erwin Heberle-Bors had a high number of participants again and organized a nice program with lectures and posters. There was attention again on pollen development and genetics as well as physiological contributions. Changes in scientific approaches became visible. Needless to say, Vienna is a very attractive city and the special dinner held at a "heuriger" was well received.

Lorne, Australia, 1996 was the venue for the XIV International Congress, organized by Prof. Bruce Knox, 
Fig. 1 Early congress logos featured various congress themes. The initial Congress in Nijmegen (1963) featured a pollinated pistil, presenting a theme that was repeated in the IV Congress in Nijmegen (1974). The High Tatra congress in Bratislava in 1982 featured a dicot and a monocot embryo, whereas the $\mathrm{X}$ Congress in Siena (1988) featured a pollinated pistil with embryo sac and embryo. The XI ISER Congress (1990) connected male and female symbols with an embryo; and for the XII Congress in Columbus (1992), a triangle with a flower was the featured symbol
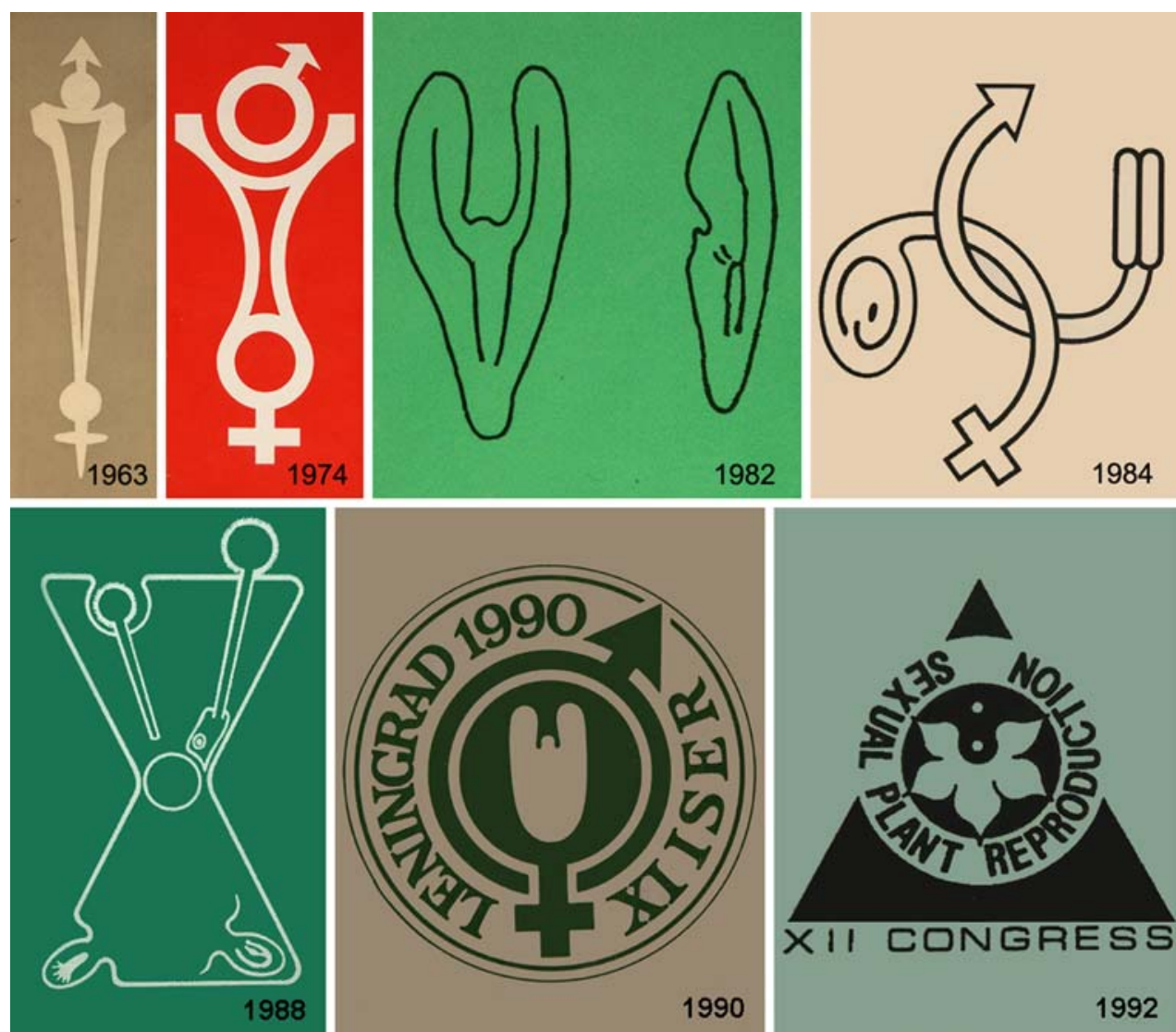

with 350 participants and an interesting, full program. New were aspects of pollen allergens and some lectures on applications in forestry. The first IASPRR awards were given. The Australian environment, ocean shores and forests near to Lorne made it a special meeting.

The XV Congress was organized in Wageningen, The Netherlands, 1998 by Prof. Michiel Willemse. In agreement with the location of the Agricultural University, there was a call to keep in mind the practical implications of the plant sexual reproduction research. The congress had a full program and about 250 scientists. The relatively small city and congress center promoted the scientific contacts.

The XVI congress was held in Banff, Canada, 2000, with Profs. Vipen Sawhney and David Cass as organizers. Morning snows and deer on paths to the meeting rooms made this a special meeting for the $\sim 130$ participants. There were no parallel sessions and the program offered a section about the environmental stress and reproduction and another about male sterility and hybrid seed production, which were quite uncommon subjects in the series. Free afternoons offered the possibility to enjoy the environment and winter sports giving a unique character to this congress. The successful sponsoring by the organizer resulted in a very good financial contribution to the IASPRR.
In 2002, the XVII congress returned to a very different Lublin, Poland than the 1978 meeting. The organizer, Prof. Józef Bednara, composed a balanced program with a large poster presentation. Growing interest in plant molecular approaches provoked the remark that scientists should be more sensitive to the consequences of their work.

Beijing, China, was selected as the site of the 2004 XVII Congress, organized by Prof. Yi-Qin Li. About 150 scientists attended, with large representation from China and a carefully crafted program that covered all aspects of sexual reproduction. For the first time, cytology and morphology formed a minority of talks. Tang Peihua (1991), visiting the congress in 1988, predicted that "the study in the field of reproduction will enter a new stage of high-speed development in the near future" and this prediction was bearing fruit during this congress.

The latest Congress (XIX ICSPR) took place in Budapest, Hungary, in 2006, and was organized by Prof. Beata Barnabás. About 270 scientists participated in nine sessions of the program, which covered various sexual plant reproduction processes, as well as some applied aspects.

In August 2008, we celebrate another milestone, which is the 20th meeting in the official series. The XX ICSPR will be held in Brasilia, Brazil, organized by Dr. Ana Claudia Guerra de Araujo of the Embrapa Institute, and 
will undoubtedly increasingly emphasize experimental, molecular and cellular approaches to understanding plant reproduction, while still encouraging presentations on biotechnology and the context of sexual systems in the natural environment.

The next congress logos show the IASPRR logo filled with a part of the world and subsequently a symbol of the place (Fig. 2). Most of the congresses have had durations of 3 or 4 days, often with social sightseeing excursions, excellent banquets and an opportunity to hear talks and posters from many research groups from around the world.

\section{Changing interests in sexual plant reproduction}

Unfortunately, not all of the congresses have resulted in separate journal issues or congress volumes. Modern publishers have found weak demand by libraries for such congress proceedings, but for us, these past works provide an historical record of the progression of interests in sexual plant reproduction research. As these congresses have attracted the experts in this field, examining this information provides insights into the growth of the area and the dynamism of approaches and topics represented.

An overview of congress presentations over 43 years is useful in seeing trends in that period concerning research approaches, subject disciplines and reproductive topics. Among the main biological disciplines, four main disciplines have been represented at the congresses: (1) genetics: classical genetics, as well as genomics and proteomics; (2) cytology: cell structure, including histochemistry, immunohistochemistry and ultrastructure; (3) morphology: plant reproductive organization, including the structure of organs and cells at the on a light microscopical level; and finally (4) physiology: functional studies, including tracing, analytical or biochemical approaches. Although there is clearly overlap between these areas, it is still interesting to see their relative contributions (Fig. 3), as evident through the published abstracts (see text references below).

As can be noted from the congresses, cytology and morphology as disciplines were prominent and even dominant up to the mid-1980s, but since then, a gradual increase in physiology evident over the life of the

Fig. 2 Since 1994, the logo of the IASPRR has been incorporated in symbolic logos for ensuing congresses. From the top left are: the logo of the IASPRR (1991), the logo for the XIII Congress in Vienna (1994), the XV Congress in Wageningen (1998), consisting of a world image over a past Wageningen University "W" logo; the XVII Congress in Lublin (2002), XVIII Congress in Beijing (2004) and XIX Congress in Budapest (2006)
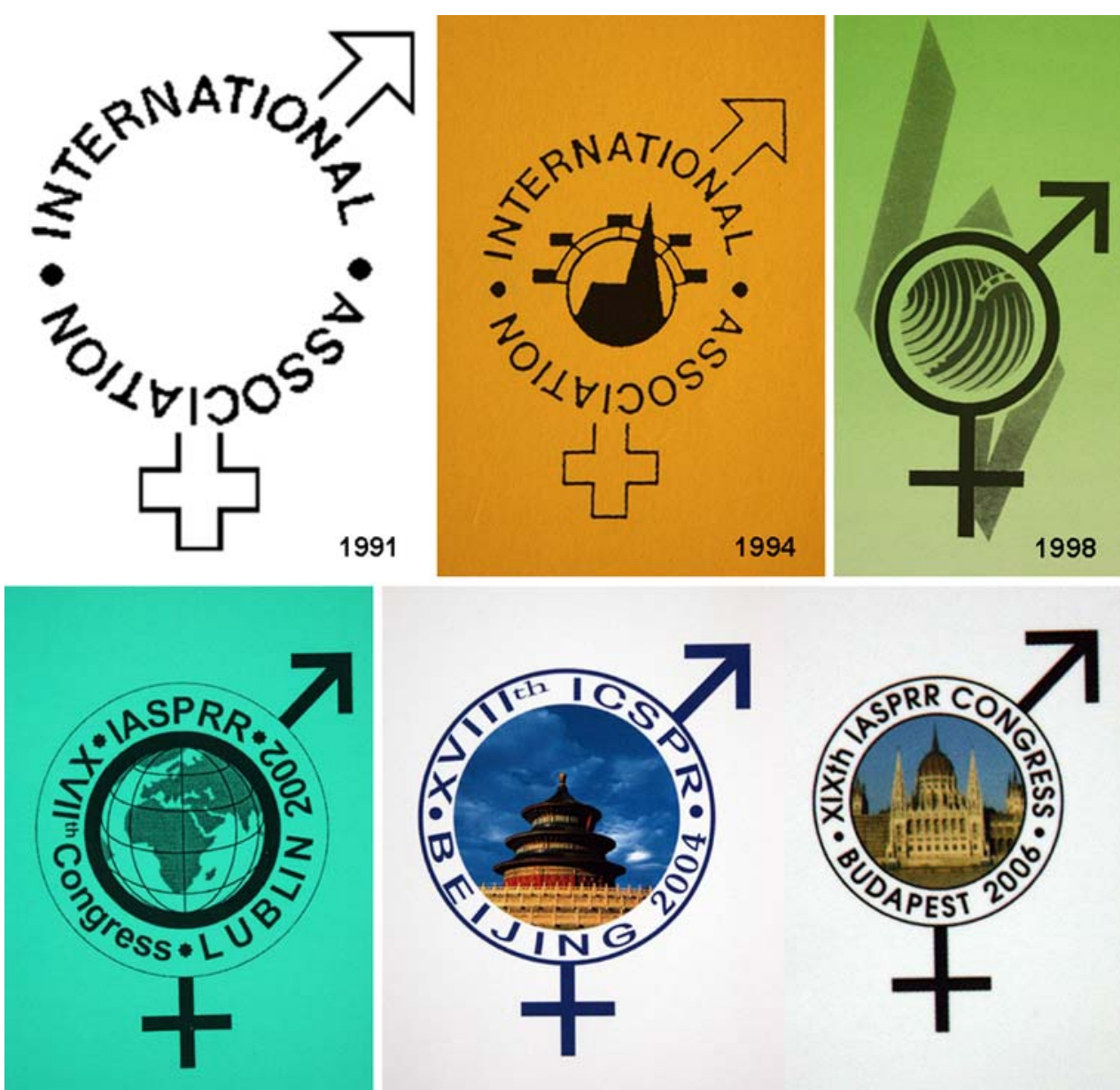

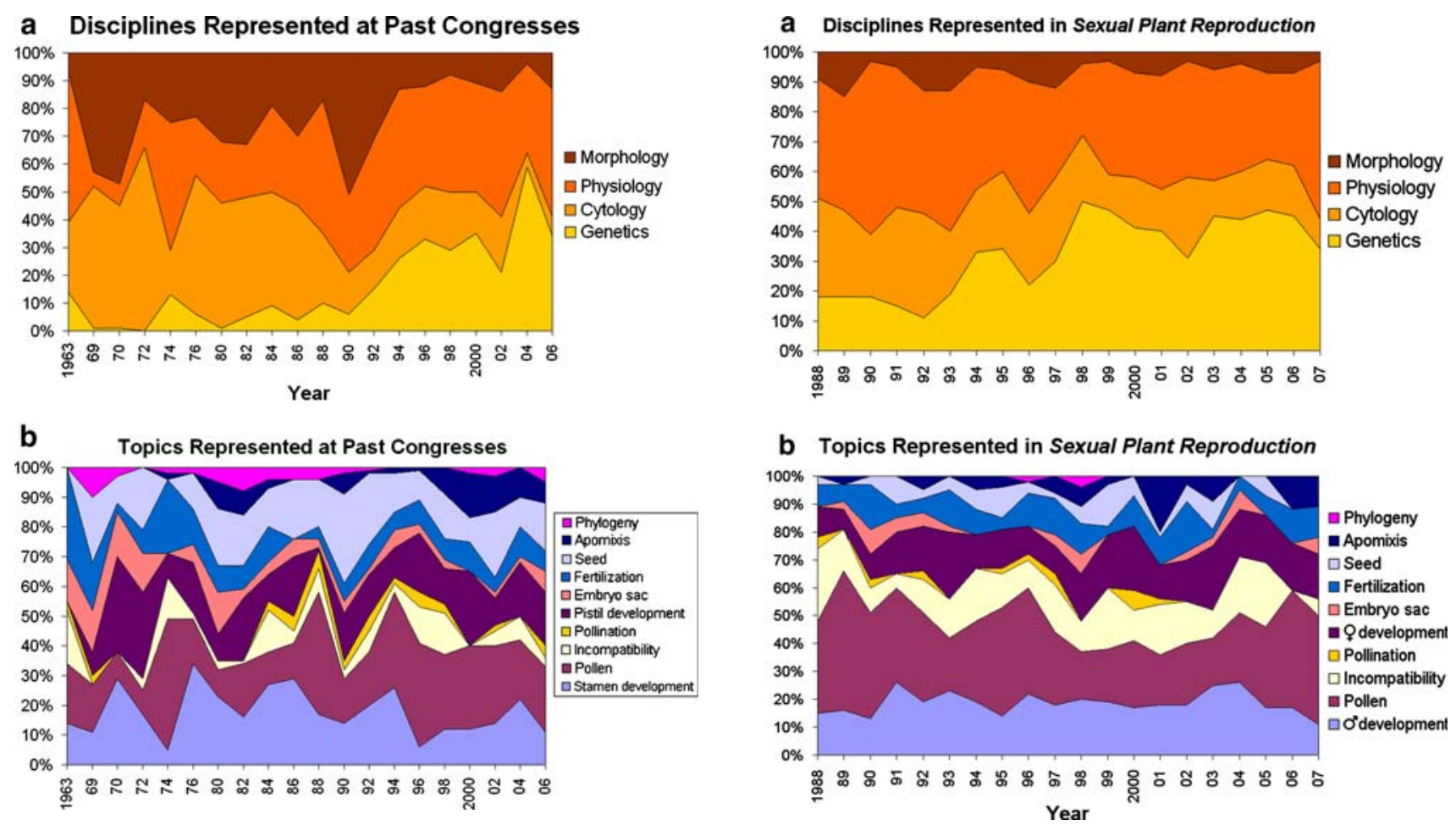

Fig. 3 Representation of disciplinary interests and topics at international sexual plant reproduction congresses, 1963-2006

congresses, has recently been surpassed by genetics in the latest meetings. As presentations represent the scientific research choices of participating laboratories, this chart can be viewed as a sampling of trends regarding disciplinary interest within the sexual plant reproduction arena. Exceptions are not difficult to note. Also, each congress has its own strengths and national character. The 1990 the Russian congress, for example, centered on morphological approaches, whereas the genomic interest of participating Chinese scientists was reflected in the 2004 Beijing congress.

The second chart in Fig. 3 depicts the topical interests of congress participants and provides insight into the relative growth and contraction of different topics. Frequencies of each of 11 selected disciplines are compared on the second chart, which depicts general and local trends in the congresses spanning 43 years. As is evident, "male" topics regarding stamens, pollen, incompatibility and pollination have traditionally filled a high percentage of the whole program. The stamen development category includes mainly pollen development including microsporogenesis and microgametogenesis, tapetum and anther wall development, and "pollen", which on this chart includes pollen wall, in vivo and in vitro tube growth, and allergies, overlap. These two male topics are two of the largest topics at many conferences and represent part of a "male bias" that is almost undoubtedly because of the ready availability

Fig. 4 Disciplines (left) and topics (right) represented in the journal Sexual Plant Reproduction congresses, 1988-2007

of subject material. The content of talks on incompatibility and pollination varies widely in representation depending on venue, host and interests. Pollination reports are linked most often to developmental aspects of pollen in relation to dispersal.

"Female" topics of interest in the program include pistil development, which includes megasporogenesis and megagametogenesis, stigma and style; embryo sacs and fertilization, including attraction, communication, and fusion. Both female development and fertilization are important areas but second in number of contributions. Apomixis, seed production (the diaspore, including seed, embryo, endosperm and fruit) and phylogenies are represented in a set of topics that involve general or evolutionary aspects of the life cycles.

Sexual Plant Reproduction as a journal has been published since 1988 and shows its own trends in discipline and topic representation (Fig. 4). The journal, of course, presents a far more formal means of communication that is guided by a managing editor and editorial board, reviewers and contributors, which each represent their own interests in the published work of the journal. Interestingly, the disciplinary representation has remained reasonably highly represented in physiology papers, but has never seen the same domination by morphology or cytology, though certainly genetic approaches have come to represent nearly half of published works. Under the guidance of three 
Fig. 5 Front and reverse faces of the IASPRR medal
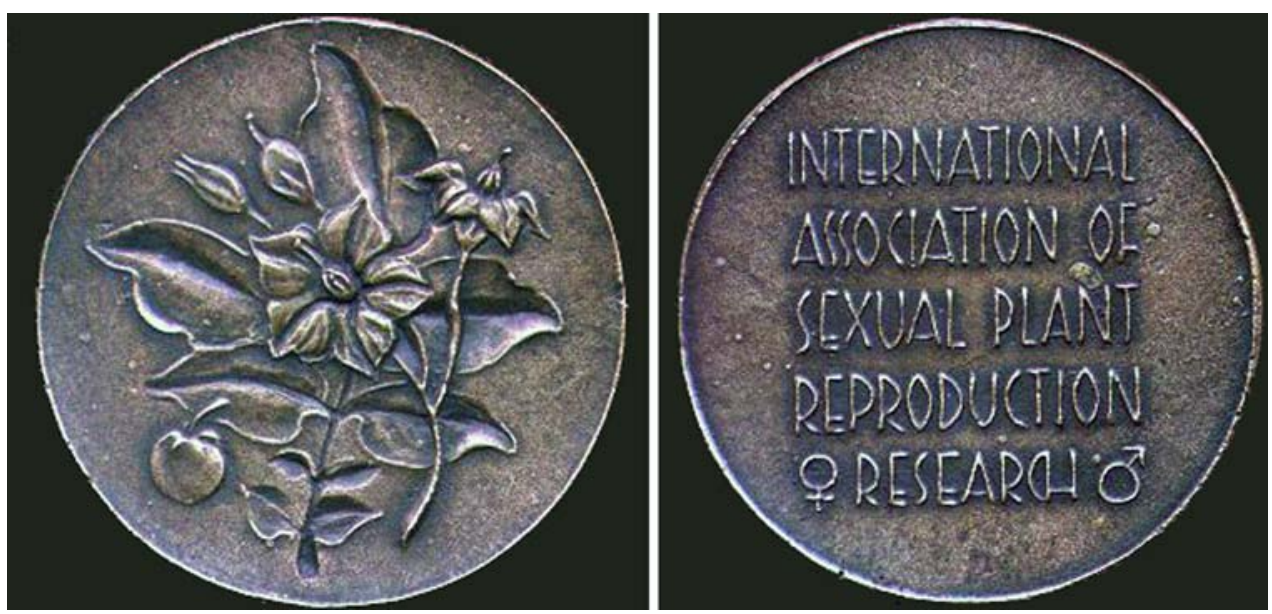

managing editors (Hans Ferdinand Linskens beginning in 1988-1993, Joseph Mascarenhas from 1993-2001, and Scott Russell from 2001 to the present), the growth and changes in the areas served by the journal are reflected in its published articles.

The life of the journal, though shorter than that of the congresses, reflects similar changes in topical coverage as well, compared with the congresses. Over the 20 international congresses and the 20 volumes of the journal, comparing mean percentages between these topics shows remarkable congruence. The mean averages per topic are (for congresses and journal, respectively): stamen development $=18$ versus $19 \%$; pollen $=21$ versus $29 \%$; incompatibility $=6$ versus $14 \%$; pollination $=2 \%$ (both); pistil development $=15 \%$ (both); embryo sac $=6$ versus $3 \%$; fertilization $=10$ versus $9 \%$; Seed $=15$ versus $5 \%$; apomixis $=4 \%$ (both); and phylogeny $=3$ versus $0.3 \%$. This is an interesting starting point as it is perhaps more similar than the disciplinary representation. Seed, including embryo, endosperm and fruit, has had more attention in congresses than in the journal. Apomixis, a topic that was a special issue of the journal, has now moved into a fixed place in reproduction research. Phylogeny and topics of general or evolutionary aspects is not as highly represented as one might anticipate based on sexual plant reproductive diversity, but has received a bit more attention in congresses.

Ironically, a major difference is that congress seems to balance percentages of male and female coverage better, 47 and $46 \%$, respectively compared to the journal in which matters of male reproduction have seemingly dominated, 63 and $32 \%$, respectively. One might presume that the difficulties in working with female topics are quite a bit greater than those required to produce publishable results in males. Presumably, in the 21 st century, genetic and physiological methods will gain greater prominence. More balanced coverage of males and females in the journal is only likely once techniques to examine female lineages provide abundant enough high quality material to complete with the males as scientific subjects, or whether the female coverage has simply moved to other journals.

\section{Other IASPRR activities}

One of the activities of the Association is the stimulation of the young scientists by offering an award for the best lecture and poster. The Linskens lecture award and the newly named Willemse poster award consisted in the beginning of an IASPRR medal and for the poster a nice charter but these awards now carry a monetary value as well. The medal of the Association showcases the fine artistic abilities of Mrs. Ingrid Linskens. The front represents a flowering potato plant, which is familiar to many researchers in plant reproduction. The Solanaceae is a well known family for studying gametophytic self incompatibility and source of crops important as well for their direct agricultural use. The reverse side displays an imprint of the name of the Association and its iconic logo. The medal has been cast in both bronze and crude silver. Both sides of the medal are represented in Fig. 5.

Another activity of the Association was distribution of a simple newsletter with IASPRR reports, finances, fees and important announcements, as well as information about related books or activities. This newsletter provided information that was especially appreciated in countries isolated normal scientific communication. With the advent of the Internet, the Plant-Repr net was an early listserv covering plant reproduction topics, but spam bombarded this unprotected list and it faded. In 1996, Prof. Scott Russell started a very nice and informative web site: http://www.iasprr.org/. The site is frequently visited and it presents the aims of the IASPRR, constitutions and bylaws, the former and coming congresses and has educational and research links. Among other subjects of interest, the web 
page provides links and information about the journal Sexual Plant Reproduction, as well as the possibility to become an IASPRR member by a mail-in form and has some resources on plant reproduction that are useful for education. The site remains up-to-date.

The connection between IASPRR with the journal Sexual Plant Reproduction is largely one of shared participation, as many of the selected reviewers and contributors are members and member can enjoy a highly discounted personal subscription price. In 1988, at the Berlin International Botanical Congress, the first volume of the journal Sexual Plant Reproduction was introduced.

\section{Future}

Although the IASPRR had a strongly European origin, it has since become quite worldwide, with a membership that includes scientists from over 42 countries. From its beginnings in the 1960s, the growing impact of this series of congresses has grown, with scientific contacts and congress publications in journals and books forming the basis of the journal and IASPRR. Today and in the future, these elements will clearly support the science of plant sexual reproduction.

The importance of stimulating young scientists to continue their research on sexual plant reproduction can not be overestimated. The journal, the organization and international congresses will play a continuing role in meeting this challenge in the future. As we decipher the molecular bases of plant development, plant sexual reproduction research can no longer remain separated from our looming agricultural crises. Yet, we can only remain optimistic that some of the greatest challenges to research in this field in the future will be met through molecular biology and the wise use of genetic tools to improve plants.

From the survey of congresses, it is clear that the genomics and physiology areas will continue to dominate the other disciplines for some time to come. It should be kept in mind that many of the processes active in sexual reproduction are prepared long before they are expressed. Interactions during plant sexual reproduction between different organisms, the mother plant, and with the environment should also be kept in mind and need more attention. With increased reliance on model species for molecular studies, knowledge and continued basic studies on the diversity of plants will likely be needed to provide some of our most crucial breakthroughs. Education cannot be deferred in this important area of science as our crop plants are reliant on sexual processes for many of their greatest successes. In this process, such congress series promote the communication of ideas and research that such symposia seem to be becoming more frequent rather than less, despite our electronic connectedness. Helping to aid communication in countries under-represented in science is also fostered by such congresses, writing papers in journals, newsletters, presentations, web sites and networks.

The IASPRR will continue to bring together scientists and expand its network. By the organization of a good congress series, which provide stimulation to young scientists, the association will have a major impact on the future of the sexual plant reproduction research. Therefore it is good to say: join the IASPRR!

\section{Congress publications and organizers}

Linskens HF (ed) (1964) Pollen Physiology and Fertilization. North-Holland Publishing Company, Amsterdam, Netherlands, 257 pp

Favre-Duchartre M (1969) Colloque sur les Aspects Cytologiques de la Reproduction Sexuée des Plantes Ovules. Revue de Cytology et de Biologie Vegetales XXXII: $400 \mathrm{pp}$

Favre-Duchartre M (1971) Colloque sur les Aspects Cytologiques des Gamétogénèses Femelles et Mâles chez les Cormophytes. Les Annales de l'Universitè et de l'ARERS 9: 237p

Sarfatti G (1973) From Ovule to Seed: Ultrastructural and Biochemical Aspects. Caryologia 25 suppl. 314 pp Linskens HF (ed) (1974) Fertilization in Higher Plants. North-Holland Publishing Company, Amsterdam, Netherlands $373 \mathrm{pp}$

Favre-Duchartre M (1976) Cytobiologie de la Reproduction Sexuée des Plantes Ovules. (Riems, France). Bulletin de la Société Botanique de France 125: 299 pp Rodkiewicz B (1981) Advances in Plant Cytoembryology. Acta Societatis Botanicorum Poloniae 50:356 pp

Erdelská O (ed) (1983) Fertilization and Embryogenesis in Ovulated Plants. Slovenskej Akadémie, Bratislava, $384 \mathrm{pp}$

Willemse MTM, Went JL van (comp) (1984) Sexual Reproduction in Seed Plants, Ferns and Mosses. Pudoc, Wageningen, $206 \mathrm{pp}$

Favre-Duchartre M (1986) Neuvième Colloque International de Cytobiologie de la Reproduction Sexuée des Plantes Superieures. Les Annales de l'Universitè et de l'ARERS 23: 182p

Cresti M (ed) (1988) Sexual Reproduction in Higher Plants. Springer-Verlag Berlin Heidelberg New York London Paris Tokyo, 502p

Batygina T (ed) (1990) XI International Symposium Embryology and Seed Reproduction. St. Petersburg Nauka, $670 \mathrm{pp}$

Jensen W (1992) Program of the XII International Congress on Sexual Plant Reproduction: Plant Reproductive Biology, Pollen, Ovules and Seeds 
Heberle-Bors (1995) Frontiers in sexual plant reproduction research. Protoplasma 187: $191 \mathrm{pp}$

Knox BR (1996) Program of the 14th International Congress on Sexual Plant Reproduction: Plant reproduction '96

Willemse MTM (1999) XVth International Congress on Sexual Plant Reproduction: Regulation, Development Interaction. Protoplasma 208: $274 \mathrm{p}$

Sawhney VK (2000) Program of the XVIth International Congress on Sexual Plant Reproduction

Bednara J (2002) Sexual Plant Reproduction in Nature and the Laboratory. Acta Biologica Cracoviensa 45: $176 \mathrm{p}$

Li Yi-Qin (2004) Program of the 18th International Congress on Sexual Plant Reproduction

Barnabás B (2006) Program of the 19th International Congress on Sexual Plant Reproduction. From gametes to genes

Araujo ACG (2008) Brazil coming XX International Congress on Sexual Plant Reproduction

Acknowledgments The author thanks the IASPRR for the invitation to write this history and for all other honors given. Thanks also to the congress accompanying person Mrs. A.Willemse-Jacobs for the critical reading of the manuscript.

Open Access This article is distributed under the terms of the Creative Commons Attribution Noncommercial License which permits any noncommercial use, distribution, and reproduction in any medium, provided the original author(s) and source are credited.

\section{References}

Bednara J (1996) (ed) Acta societatis botanicorum poloniae 65:1-199 Cresti M, Linskens HF (1999) The discovery of sexual reproduction in higher plants. Acta Biol Crac Ser Bot 41:19-29

Hesse M (1987) Karl Schnarf - a plant embryologist between the World Wars. Atti Soc Tosc Sci Nat Mem Ser B 94:181-187

Kapil RN (1967) Some contributions of professor P. Maheshwari to botany. Phytomorphology 17:1-23

Kuta E (2005) (ed) Acta biologica cracoviensia 47:1-245

Maheshwari P (1962) Plant embryology. Sangam Press, Poona, 273 $\mathrm{pp}$

Mulcahy DL, Bergamini Mulcahy G, Ottaviano E (1986) Biotechnology and ecology of pollen. Springer, New York, pp 528

Ottaviano E, Mulcahy DL, Sari Corla M, Bergamini Mulcahy G (1992) Angiosperm pollen and ovules. Springer, New York, pp 465

Tang Peihua (1991) Advances in research on reproductive biology in higher plants-view of previous international symposia on sexual reproduction in higher plants. Bot Res 6:28

van der Pluijm JE (1964) An electron microscopic investigation of the filiform apparatus in the embryo sac of Torenia fournieri. In: Linskens HF (ed.) Pollen physiology and fertilization. NorthHolland Publ Co, Amsterdam, pp 8-16

Žárský V, Tupý J (1995) A missed anniversary: 300 years after Rudolf Jacob Camerarius' "De sexu Plantarum epistola". Sex Plant Reprod 8:375-376 